\title{
Characterization of Vanadium Oxide Supported on Zirconia and Modified with $\mathrm{MoO}_{3}$
}

\author{
Jong Rack Sohn, ${ }^{*}$ Ki Cheol Seo, and Young II Pae ${ }^{\dagger}$ \\ Dept. of Industral Chemistry, Engineering C'ollege, Kunngook Aational Lmiversity, Daegu 702-701, Korea \\ Dept. of ('hemistry, Thiversin of Ilsan, THsan 680-749, Korea \\ Received Juhy 19, 2002
}

\begin{abstract}
Vanadium oxides supported on zirconia and modified with $\mathrm{MoO}$ ) were prepared by adding $\operatorname{Lr}\left(\mathrm{OH} \mathrm{L}_{\mathrm{1}}\right.$ powder into a mixed aqueous solution of ammonium metavanadate and ammonium moly bdate followed by drying and calcining at high temperatures. The characterization of prepared catalysts was performed using FI IR, Raman spectroscopy and solid-state ${ }^{51} \mathrm{~V}$ NMR, In the case of a calcination temperature of $773 \mathrm{~K}$, for samples containing low loading of $\mathrm{V}_{2} \mathrm{O}_{3}$, below $15 \mathrm{wt} \%$, vanadium oxide was in a highly dispersed state, while for samples containing high loading of $\mathrm{V}_{2} \mathrm{O}_{5}$, equal to or above $15 \mathrm{wt} \%$, vanadium oxide was well crystallized becalse the $\mathrm{V}_{2} \mathrm{O}_{5}$ loading exceeded the formation of a monolaver on the surface of $\angle \mathrm{rO}$. The $\angle \mathrm{rV}_{2} \mathrm{O}$ compound was formed through the reaction of $\mathrm{V}_{2} \mathrm{O}_{5}$ and $\mathrm{ZrO} 2$ at $873 \mathrm{~K}$ and the compound decomposed into $\mathrm{V}_{2} \mathrm{O}_{3}$ and $\angle \mathrm{rO}_{2}$ at $1073 \mathrm{~K}$, which were confirmed by F"lIR spectroscopy and solid-state ${ }^{51} \mathrm{~V}$ NMR. IR spectrosicopic studies of ammonia adsorbed on $\mathrm{V}_{2} \mathrm{O}_{5}-\mathrm{MoO}_{3} / \angle \mathrm{rO} \mathrm{O}_{2}$ showed the presence of both Lewis and Brönsted acids.
\end{abstract}

Key Words : Characterization, $\mathrm{V}_{2} \mathrm{O}_{5}-\mathrm{M}_{0} \mathrm{O}_{3} / 7 . \mathrm{rO}_{2}{ }^{51} \mathrm{~V} \mathrm{NMR}, \mathrm{FTIR}, \mathrm{XRD}$

\section{Introduction}

Vanadium oxides are widely used as cataly sts in oxidation reactions, for example. the oxidation of sulfur dioxide. carbon monoxide. and hydrocarbons. ${ }^{1-4}$ These systems have also been found to be effective catalysts for the oxidation of methanol to methy lformate and for the ammoxidation of 3picoline? Vanadia catalysts supported on titania-alumina mixed oxide and titania modified with alumina were found to exhibit superior activities in selective catalytic reduction of NOx ${ }^{8-11}$ Much research has been done to understand the nature of active sites, the surface structure of catalysts as well as the role played by the promoter of the supported catalysts. using infrared (IR). X-ray diffraction (XRD), electron spin resonance (E.S.R) and Raman spectroscop: ${ }^{12-14}$ So far. silica. titania. zirconia and alumina $a^{1-21}$ have been commonly employed as the vanadium oxide supports.

Recently; metal oxides modified with sulfur compounds have been studied as strong solid acidic catalysts, ${ }^{2--14}$ especially sulfate promoted zirconia containing iron or manganese as promoters ${ }^{2}$ or noble metals to inlubit deactivation. The high catalytic activity and small deactivation upon the addition of noble metals can be explained by both the elimination of coke by hydrogenation and hydrogenoly sis. ${ }^{-9}$ and the formation of Brönsted acid sites from $\mathrm{H}_{2}$ on the

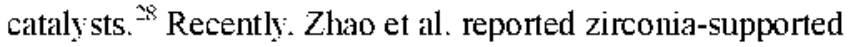
molybdemum oxide as an alternative material for reactions requiring strong acid sites. ${ }^{\text {?ci }}$ Several adsantages of molybdate, over sulfate. as dopant include that it does not suffer from dopant loss during thermal treatment and it undergoes significantly less deactivation during cataly tic reactions. ${ }^{31}$ So far. however. comparatively few studies have been reported

"Corresponding author. F-mllail: jrsohnig knuac.k on binary oxide, vanadium oxide-molybdenum oxide supported on zirconia.

It is well known that the dispersion and the structural features of supported species are strongly dependent on the support. The promoting effect of a $\mathrm{TiO}_{2}$ support on the oxidation of o-xylene on $\mathrm{V}_{2} \mathrm{O}_{5}$ has been ascribed to an increase of the number of surface $\mathrm{V}=\mathrm{O}$ bonds on the $\mathrm{V}_{2} \mathrm{O}_{5} /$ $\mathrm{TiO}_{2}$ catalysts and weakening of these bonds. ${ }^{32}$ ln many studies concerning the mechanism of the catalytic reactions on vanadium oxide, the $\mathrm{V}=\mathrm{O}$ species have been considered to play a significant role as the active sites for the reactions. i.i. Structure and other physicochemical properties of supported metal oxides are considered to be in different states compared with bulk metal oxides because of their interaction with the supports. Solid-state nuclear magnetic resonance (NMR) methods represent a novel and promising approach to these systems. Since only the local ein iromment of a nucleus under study is probed by NMR, this method is well suited for the stnictural analysis of disordered systems such as the twodimensional surface vanadium oxide phases which is of particular interest in the present study. In addition to the stnictural information provided by NMR methods. the direct proportionality of the signal intensity to the number of contributing muclei makes NMR be useful for quantitative studies. In the present investigation. the techniques of solidstate ${ }^{51}$ V NMR and Fourier transform infrared (FTIR) have been utilized to characterize a series of $\mathrm{V}_{2} \mathrm{O}_{5}$ samples supported on $\mathrm{ZrO}_{2}$ and modified with $\mathrm{MoO}_{3}$.

\section{Experimental Section}

Catalyst Preparation. Precipitate of $\mathrm{Zr}(\mathrm{OH})_{1}$ was obtained by adding aqueous ammonia slowly into an aqueous solution of zirconium oxychloride (Aldrich) at room temperature 
with stirring until the $\mathrm{pH}$ of mother liquor reached about 8 . The precipitate thus obtained was washed thoroughly with distilled water until clloride ion was not detected by $\mathrm{AgNO}_{3}$ solution. and was dried at room temperature for $12 \mathrm{~h}$. The dried precipitate was powdered below 100 mesh.

The catalysts containing various vanadium oxide content and modified with $\mathrm{MoO}_{3}$ were prepared by adding $\mathrm{Zr}(\mathrm{OH})_{1}$ powder into a mixed aqueous solution of ammonium metavanadate ( $\left.\mathrm{NH}_{4} \mathrm{VO}_{3}\right)$ (Aldrich) and ammonium molybdate $\left\lfloor\left(\mathrm{NH}_{3}\right)_{6}\left(\mathrm{Mo}_{-} \mathrm{O}_{-1}\right)\left(4 \mathrm{H}_{2} \mathrm{O}\right)\right.$ (Aldrich) followed by drying and calcining at high temperatures for $1.5 \mathrm{~h}$. This series of catalysts were denoted by their weight percentage of $\mathrm{V}_{2} \mathrm{O}_{5}$ and $\mathrm{MoO}_{3}$ and calcination temperature. For example, $3 \mathrm{~V}_{2} \mathrm{O}_{5-}$ $15 \mathrm{MoO}_{3} / \mathrm{ZrO}_{2}(773)$ indicated the catalyst containing $3 \mathrm{wt} \%$ $\mathrm{V}_{2} \mathrm{O}_{5}$ and $15 \mathrm{wt} \% \mathrm{MoO}_{3}$ calcined at $773 \mathrm{~K}$.

Characterization. FTIR absorption spectra of $\mathrm{V}_{2} \mathrm{O}_{5}-$ $\mathrm{MoO}_{3} / \mathrm{ZrO}_{2}$ powders were measured by $\mathrm{KBr}$ disk method over the range $1200-400 \mathrm{~cm}^{-1}$. The samples for the $\mathrm{KBr}$ disk method were prepared by grinding a mixture of the catalyst and $\mathrm{KBr}$ powders in an agate mortar and pressing them in the usual way. FTIR spectra of ammonia adsorbed on the catalyst were obtained in a heatable gas cell at room temperature using a Mattson Model GL 6030E spectrophotometer. The self-supporting catalyst wafers contained about $9 \mathrm{mg} /$ $\mathrm{cm}^{2}$. Before the spectra were obtained, the samples were heated under vacuum at $673-773 \mathrm{~K}$ for $1.5 \mathrm{~h}$.

The FT-Raman spectra were obtained with a Bruker model FRA 106 A spectrometer equipped with an lnGaAs detector and a Nd:YAG laser source with a resolution of $4 \mathrm{~cm}^{-1}$. The laser beam was focussed onto an area $0.1 \times 0.1 \mathrm{~mm}^{-}$in size of the sample surface: a $180^{\circ}$ scattering geometry was used.

${ }^{51} \mathrm{~V}$ NMR spectra were measured by a Varian Unity lnova 300 spectrometer with a static magnetic field strength of $7.05 \mathrm{~T}$. Lamor frequency was $78.89 \mathrm{MHz}$. An ordinary single pulse sequence was used, in which the pulse width was set at $2.8 \mathrm{~s}$ and the acquisition time was $0.026 \mathrm{~s}$. The spectral width was $500 \mathrm{kHz}$. The number of scans was varied from 400 to 4.000 . depending on the concentration of vanadium. The signal was acquired from the time point $+\mathrm{s}$ after the end of the pulse. The sample was static. and its temperature was ambient $(29+\mathrm{K})$. The spectra were expressed with the signal of $\mathrm{VOCl}_{i}$ being $0 \mathrm{ppm}$. and the higher frequency shift from the standard was positive. Practically, solid $\mathrm{NH}_{4} \mathrm{VO}_{3}(-571.5$ ppm) was used as the second external reference. ${ }^{34-36}$

\section{Results and Discussion}

Infrared Spectra. Figure 1 shows IR spectra of $\mathrm{V}_{2} \mathrm{O}_{-}-$ $15 \mathrm{MoO}_{3} / \mathrm{ZrO}_{2}(773)$ catalysts with various $\mathrm{V}_{2} \mathrm{O}_{5}$ contents calcined at $773 \mathrm{~K}$ for $1.5 \mathrm{~h}$. Although with samples having less than 18 wt \% of $\mathrm{V}_{2} \mathrm{O}_{5}$ definite peaks were not observed. the absorption bands at 1022 and $818 \mathrm{~cm}^{-1}$ appeared for $15 \mathrm{~V}_{2} \mathrm{O}_{5}-15 \mathrm{MoO}_{3} / \mathrm{ZrO}_{2}, \quad 20 \mathrm{~V}_{2} \mathrm{O}_{5}-15 \mathrm{MoO}_{3} / \mathrm{ZrO}_{2} . \quad 25 \mathrm{~V}_{2} \mathrm{O}_{-}-$ $15 \mathrm{MoO}_{3} / \mathrm{ZrO}_{2}$ and pure $\mathrm{V}_{2} \mathrm{O}_{5}$ containing high $\mathrm{V}_{2} \mathrm{O}_{\text {i content. }}$ c The band at $1022 \mathrm{~cm}^{-1}$ was assigned to the $\mathrm{V}=\mathrm{O}$ stretching vibration. while that at $818 \mathrm{~cm}^{-1}$ was attributable to the coupled vibration between $\mathrm{V}=\mathrm{O}$ and to $\mathrm{V}-\mathrm{O}-\mathrm{V}$ ? $^{2 ?}$ Gene-

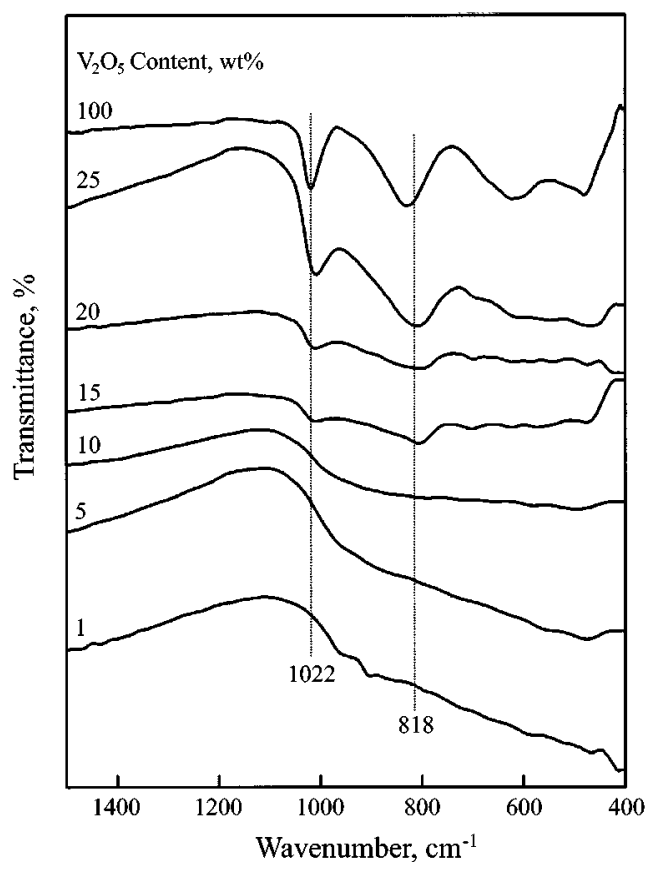

Figure 1. Intrared spectra of $\mathrm{V}_{2} \mathrm{O}_{5}-15 \mathrm{MoO}_{3} / 7 \mathrm{rO}_{2}(773)$ cataly'sts with dillierent $\mathrm{V}_{2} \mathrm{O}_{5}$ conlents.

rally: the IR band of $\mathrm{V}=\mathrm{O}$ in crystalline $\mathrm{V}_{2} \mathrm{O}_{5}$ showed at $1020-1025 \mathrm{~cm}^{-1}$ and the Raman band at $995 \mathrm{~cm}^{-1}$. 238 The intensity of the $\mathrm{V}=\mathrm{O}$ absorption gradually decreased with increasing $\mathrm{ZrO}_{2}$ content. although the band position did not change. This observation suggests that vanadium oxide below $15 \mathrm{wt} \%$ is in a highy dispersed state. It is reported that $\mathrm{V}_{2} \mathrm{O}_{5}$ loading exceeding the formation of monolayer on the surface of $\mathrm{ZrO}_{2}$ is well crystallized and observed in the spectra of $\mathrm{IR}$ and solid state ${ }^{51} \mathrm{~V}$ NMR. ${ }^{3+3 / i}$

It is necessary to examine the formation of crystalline $\mathrm{V}_{2} \mathrm{O}_{5}$ as a function of calcination temperature. Variation of IR spectra against calcination temperature for $3 \mathrm{~V}_{2} \mathrm{O}_{5}-15 \mathrm{MoO}_{3} /$ $\mathrm{ZrO}_{2}$ is shown in Figure 2. There were no $\mathrm{V}=\mathrm{O}$ stretching bands at $1022 \mathrm{~cm}^{-1}$ at calcination temperatures from 673 to $973 \mathrm{~K}$. indicating no formation of crystalline $\mathrm{V}_{2} \mathrm{O}_{5}$. However. as shown in Figure 2. $\mathrm{V}=\mathrm{O}$ stretching bands due to crystalline $\mathrm{V}_{2} \mathrm{O}_{3}$ at 1073 and $1173 \mathrm{~K}$ appeared at $1022 \mathrm{~cm}^{-1}$ together with lattice vibration bands of $\mathrm{V}_{2} \mathrm{O}_{5}$ and $\mathrm{MoO}_{3}$ below 900 $\mathrm{cm}^{-1} .39$ The formation of crstalline $\mathrm{V}_{2} \mathrm{O}_{5}$ at above $1073 \mathrm{~K}$ can be explained in terms of the decomposition of $\mathrm{ZrV}_{2} \mathrm{O}$ compound which was formed through the reaction of $\mathrm{V}_{2} \mathrm{O}_{3}$ and $\mathrm{ZrO}_{2}$ at $873-973 \mathrm{~K}$. In this study: on X-ray diffraction patterns the cubic phase of $\mathrm{ZrV}_{2} \mathrm{O}$ - was obsenced in the samples calcined at $873 \mathrm{~K}$ and for sample calcined at $1173 \mathrm{~K}$ the $\mathrm{ZrV}_{3} \mathrm{O}$ - phase disappeared due to the decomposition of $\mathrm{ZrV}_{2} \mathrm{O}_{\text {? }}$ leaving the $\mathrm{V}_{2} \mathrm{O}_{5}$ phase and the monoclinic phase of $\mathrm{ZrO}_{2}$. These results are in good agreement with those of ${ }^{51} \mathrm{~V}$ solid state NMR described later. In fact. it is known that the formation of $\mathrm{ZrV}_{2} \mathrm{O}_{2}$ from $\mathrm{V}_{3} \mathrm{O}_{5}$ and $\mathrm{ZrO}_{2}$ occurs at calcination temperature of $873 \mathrm{~K}$ and the $\mathrm{ZrV}_{2} \mathrm{O}$ - decomposes

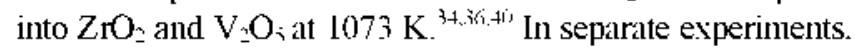
variation of IR spectra against calcination temperature for $10 \mathrm{~V}_{3} \mathrm{O}_{5}-15 \mathrm{MoO}_{4} / \mathrm{ZrO}_{2}$ (not shown in the Figure) was similar 


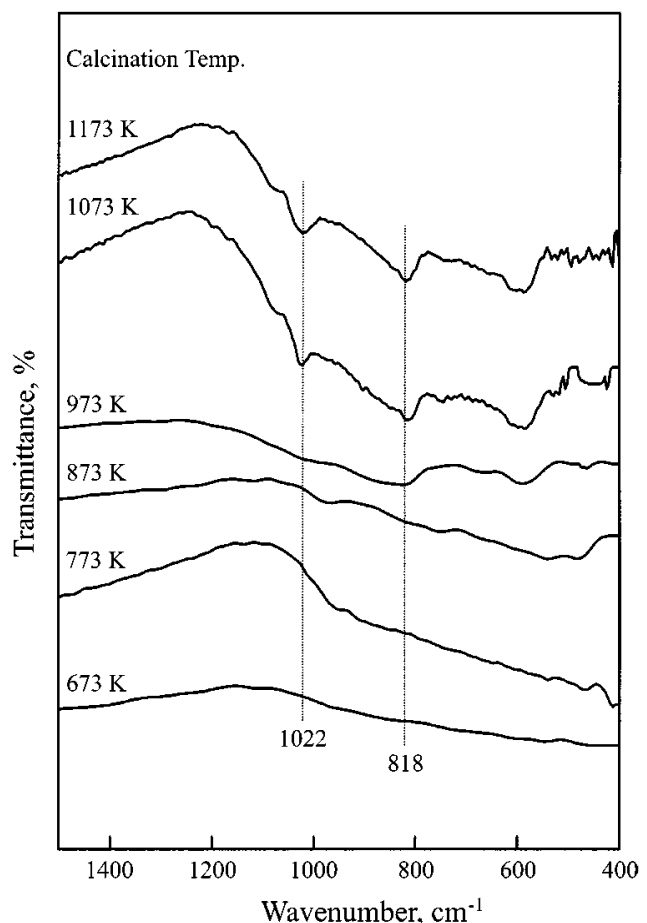

Figure 2. Inliared spectra of $3 \mathrm{~V}_{2} \mathrm{O}_{5}-15 \mathrm{MOO}_{3} / \angle \mathrm{rO}_{2}$ calalysts calcined at diflerent temperatures.

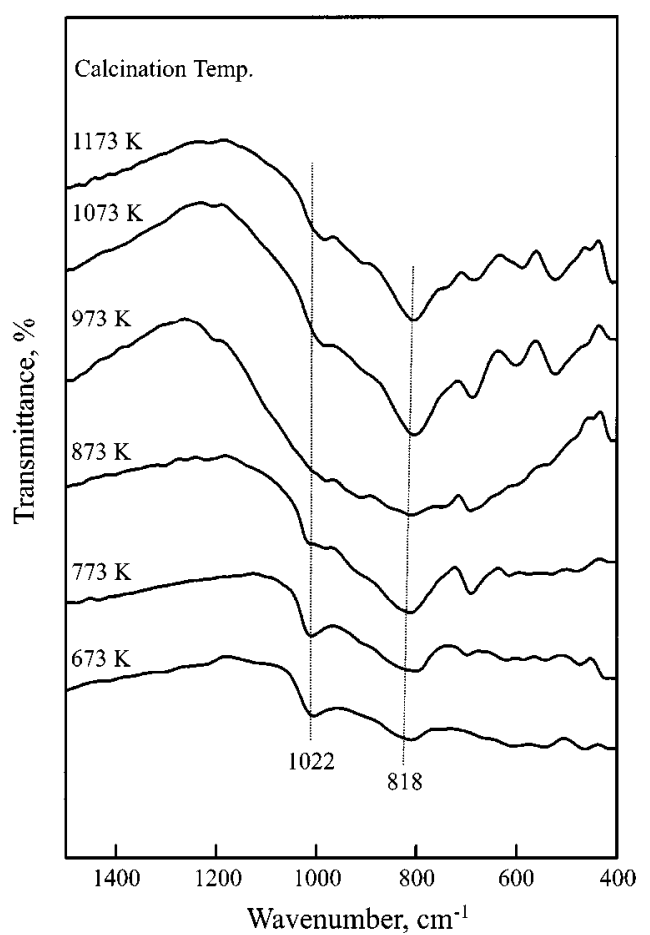

Figure 3. Inffared spectra of $20 \mathrm{~V}_{2} \mathrm{O}$ - $-15 \mathrm{MoO} / 7 \mathrm{TO}_{2}$ catalysts calcined at different temperatures.

to that for $3 \mathrm{~V}_{2} \mathrm{O}_{5}-15 \mathrm{MoO}_{2} / \mathrm{ZrO} \mathrm{r}_{2}$ as shown in Figure 2.

Figure 3 shows IR spectra of $20 \mathrm{~V}_{2} \mathrm{O}_{-}-15 \mathrm{MoO}_{3} / \mathrm{ZrO}_{2}$ catalysts calcined at $673-1173 \mathrm{~K}$ for $1.5 \mathrm{~h}$. Unlike $3 \mathrm{~V}_{2} \mathrm{O}--15 \mathrm{MoO}_{3} /$ $\mathrm{ZrO}_{2}$ and $10 \mathrm{~V}_{2} \mathrm{O}_{5}-5 \mathrm{MoO}_{4} / \mathrm{ZrO}_{2}$ catalysts. for $25 \mathrm{~V}_{2} \mathrm{O}_{i}-15 \mathrm{MoO} /$ $\mathrm{ZrO}_{2}$ crystalline $\mathrm{V}_{2} \mathrm{O}_{2}$ appeared at a lower calcination temperature from $673 \mathrm{~K}$ to $873 \mathrm{~K}$ and consequently $\mathrm{V}=\mathrm{O}$

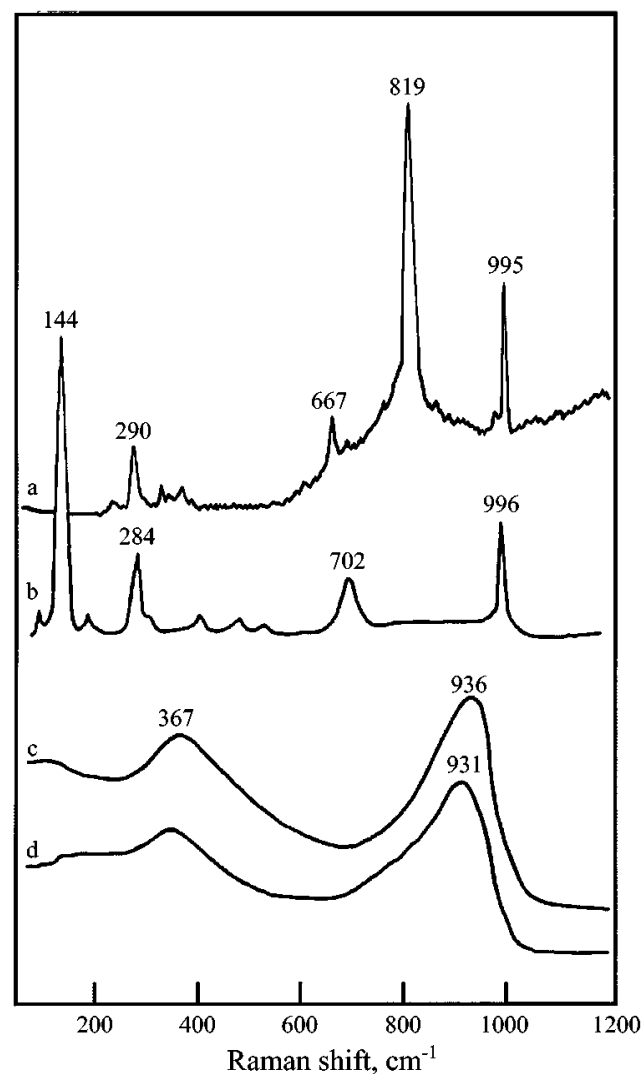

Figure 4. Raman spectra of (a) $\mathrm{MoO}_{3}$, (b) $\mathrm{V}_{2} \mathrm{O}_{-}$, (c) $10 \mathrm{~V}_{2} \mathrm{O}_{3-}$ $15 \mathrm{MoO}_{3} / 7 \mathrm{rO}_{2}(773)$, and $\left.(\mathrm{d}) 15 \mathrm{~V}_{2} \mathrm{O}_{5}-15 \mathrm{MoO}_{3} / 7 . \mathrm{rO}\right)_{3}(773)$.

stretching band was observed at $1022 \mathrm{~cm}^{-1}$. This is because a $\mathrm{V}_{2} \mathrm{O}_{5}$ loading exceeding the formation of monolayer on the surface of $\mathrm{ZrO}=$ is well crystallized. ${ }^{34}$ However. at $973 \mathrm{~K}$ all $\mathrm{V}_{2} \mathrm{O}_{5}$ reacted with $\mathrm{ZrO}_{2}$ and changed into $\mathrm{ZrV}_{2} \mathrm{O}$ - so that $\mathrm{V}=\mathrm{O}$ stretching at $1022 \mathrm{~cm}^{-1}$ disappeared completely; as shown in Figure 3.

At a calcination temperature of $1073 \mathrm{~K}$. some of the $\mathrm{ZrV}_{2} \mathrm{O}$ decomposed into $\mathrm{V}_{2} \mathrm{O}_{5}$ and $\mathrm{ZrO}_{2}$ and then $\mathrm{V}=\mathrm{O}$ stretching band due to the crystalline $\mathrm{V}_{2} \mathrm{O}_{5}$ was again observed at $\mathrm{I} 022$ $\mathrm{cm}^{-1}$. These are in good agreenent with those of ${ }^{51} \mathrm{~V}$ solidstate NMR described later

Raman spectra. Raman spectroscopy is a valuable tool for the characterization of dispersed metal oxides and detects vibrational modes surface and bulk structures. In order to analyze the mature of the surface species, laser Raman measurements of bulk $\mathrm{MoO}_{3}$. bulk $\mathrm{V}_{2} \mathrm{O}_{5}$ and $\mathrm{V}_{2} \mathrm{O}_{5}-\mathrm{I}_{5} \mathrm{MoO}_{3} /$ $\mathrm{ZrO}_{2}$ samples calcined at $773 \mathrm{~K}$ and with different vanadium oxide loadings were made. Figure + shows Raman spectra of four samples under ambient condition. Bulk $\mathrm{MoO}_{i .}$ obtained by calcining ammonium molybdate at $773 \mathrm{~K}$. shows the main bands in good agreement with data previously reported. ${ }^{\text {11.42 }}$ The major vibrational modes of $\mathrm{MoO}_{3}$ [Figure +(a)] are located at 995.819 .667 and $290 \mathrm{~cm}^{-1}$. and have been assigned to the $\mathrm{Mo}=\mathrm{O}$ stretching mode, the $\mathrm{Mo}-\mathrm{O}-\mathrm{Mo}$ asymmetric stretching mode. the Mo-O-Mo symmetric stretching mode. and the $\mathrm{M}=\mathrm{O}$ bending mode, respectively: ${ }^{41,+2}$

We will discuss the Raman spectrum of the bulk $\mathrm{V}_{2} \mathrm{O}_{5}$. obtained by calcining ammonium metavanadate at $773 \mathrm{~K}$. 
which is shown in Figure $4(b)$. The spectrum displayed bands at 14+. 196.284, 304. 406. $484.528,702$ and $996 \mathrm{~cm}^{-1}$. all of which are characteristic of crystalline $\mathrm{V}_{2} \mathrm{O}_{5}{ }^{43}$ The 996 $\mathrm{cm}^{-1}$ band is assigned to the vibration of the short vanadium oxygen bond nomally regarded as a $\mathrm{V}=\mathrm{O}$ species. ${ }^{+3}$ However, as shown in Figure $4(\mathrm{c})$, for $10 \mathrm{~V}_{2} \mathrm{O}_{5}-15 \mathrm{MoO}_{5} / \mathrm{ZrO}_{2}$ (773) no bands corresponding to $\mathrm{MoO}_{3}$ and $\mathrm{V}_{2} \mathrm{O}_{5}$ crystallites appear. indicating that $\mathrm{MoO}_{3}$ and $\mathrm{V}_{2} \mathrm{O}_{5}$ are in a highy dispersed state. As described in IR spectra, the catalysts at vanadia loadings below $15 \mathrm{wt} \%$ gave no absorption bands due to crystalline $\mathrm{V}_{2} \mathrm{O}_{5}$. However, as shown in Figure 4 (d). for $15 \mathrm{~V}_{2} \mathrm{O}_{5}-15 \mathrm{MoO}_{3} / \mathrm{ZrO}_{2}(773)$ containing $15 \% \mathrm{~V}_{2} \mathrm{O}_{5}$ the bands due to $\mathrm{V}_{2} \mathrm{O}_{5}$ crystalline were observed, showing good agreement with the results of IR spectra.

The molecular structure of the supported molybdenum oxide species depends on the loading. Several authors observed that the nature of sunface molybdemum species on $\mathrm{SiO}_{2}, \mathrm{Al}_{2} \mathrm{O}_{5}$. $\mathrm{TiO}_{2}$ and $\mathrm{ZrO}_{2}$ depends on the amount of $\mathrm{MoO}_{3}$. Raman bands between 910 and $980 \mathrm{~cm}^{-1}$ are usually attributed to the $\mathrm{Mo}=\mathrm{O}$ vibration of Mo species in either octahedral or tetrahedral en ironment. ${ }^{+4}$ Generally: monomolybdate or tetrahedral molybdemum oxygen species have been assigned for low $\mathrm{MoO}_{3}$ loading samples. ${ }^{+24.45}$ and two-dimensional polymolybdates or octahedral molybdenum-oxygen species with characteristic band around $950-980 \mathrm{~cm}^{-1}$. for high $\mathrm{MoO}_{3}$ loading samples. ${ }^{+2 .+4,+5}$ The frequency of Raman feature (1000$940 \mathrm{~cm}^{-1}$ ). the maximum of which shifts slightly upwards on increasing vanadium content. is assigned to the $\mathrm{V}=\mathrm{O}$ stretching mode vanadyl species in a hydrated form. ${ }^{9.46}$ Therefore. the broad band observed in the $950-1000 \mathrm{~cm}^{-1}$ region in Figure $4(\mathrm{c}$ and $\mathrm{d}$ ) will be interpreted as an overlap of three characteristic bands(two molybdenum oxide species and one vanadyl species).

For $10 \mathrm{~V}_{2} \mathrm{O}_{5}-15 \mathrm{MoO}_{3} / \mathrm{ZrO}_{2}(773)$ and $15 \mathrm{~V}_{2} \mathrm{O}_{5}-15 \mathrm{MoO}_{3} /$ $\mathrm{ZrO}_{2}(773)$ in Figure 4 (c and d). most of zirconia is amorphous to x-ray diffraction. showing tiny amount of tetragonal phase zirconia. The Raman spectrum of amorphous zirconia is characterized by a very weak and broad band at $550-600 \mathrm{~cm}^{-1}$. spectrum consisting of Raman bands in the region of 150 $640 \mathrm{~cm}^{-1} .36,+13$ Therefore the very broad band around $367 \mathrm{cml}^{-1}$ is interpreted as an overlap of amorphous and tetragonal phase zirconia.

Solid-State ${ }^{51}$ V NMR Spectra. Solid-state NMR methods represent a promising approach to vanadium oxide catalytic materials. The solid state ${ }^{\text {51 }} \mathrm{V}$ NMR spectra of $\mathrm{V}_{2} \mathrm{O}_{5}-\mathrm{MoO}_{3}$ $\mathrm{ZrO}_{2}$ catalysts calcined at $773 \mathrm{~K}$ followed by exposure to air are shown in Figure 5 . There are three types of signals in the spectra of catalysts with varying intensities depending on $\mathrm{V}_{2} \mathrm{O}_{5}$ content. At low loadings up to $10 \mathrm{wt} \% \mathrm{~V}_{2} \mathrm{O}_{5}$ a shoulder at about $-260 \mathrm{ppm}$ and an intense peak at $-590 \sim$ $-650 \mathrm{ppm}$ are observed. The former is assigned to the surface vanadium-oxygen stmictures surrounded by a distorted octahedron of oxygen atoms. while the latter is attributed to the tetrahedral vanadium-oxygen structures. ${ }^{750}$

However. the surface vanadium oxide structure is remarkably dependent on the metal oxide support material. Vandium

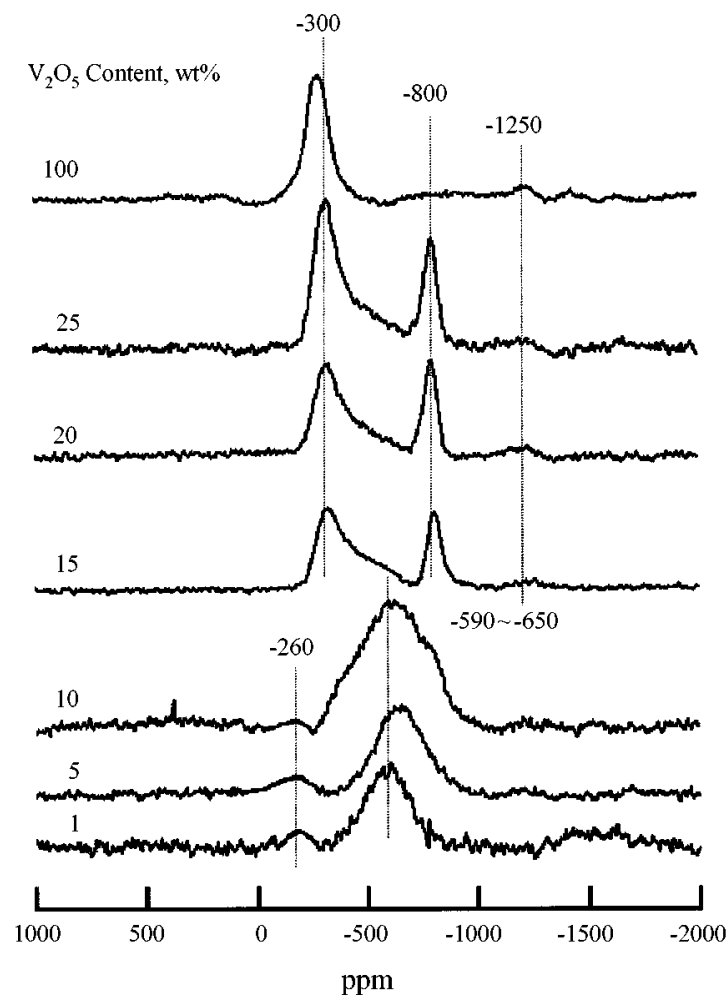

Figure 5. Solid-state " $\mathrm{V}$ NMR spectra of $\mathrm{V}_{2} \mathrm{O}_{5}-15 \mathrm{MoO}_{3} / 7 \mathrm{rO}_{2}$ (773) calalysis with dillerent $\mathrm{V}_{2} \mathrm{O}_{5}$ conlents.

oxide on $\mathrm{TiO}_{2}$ (anatase) displays the highest tendency to be 6 -coordinated at low surface coverages. while in the case of $\gamma-\mathrm{Al}_{2} \mathrm{O}_{3}$ a tetrahedral surface vanadium species is favored ${ }^{5 i)}$. As shown in Figure 5, at a low vanadium loading on zirconia a tetrahedral vamadium species is exclusively dominant compared with a octahedral species. In general. it is known that low surface coverages favor a tetrahedral coordination of vanadium oxide, while at higher surface coverages vanadium oxide becomes increasingly octahedral-coordinated.

lncreasing the $\mathrm{V}_{2} \mathrm{O}_{5}$ content on the zirconia surface changes the shape of the spectrum to a rather intense and sharp peak at about $-300 \mathrm{ppm}$ and a broad low-intensity peak at about -1250 ppm, which are due to the crystalline $\mathrm{V}_{2} \mathrm{O}_{5}$ of square py ramid coordination. ${ }^{49}$ These obsenations of crystalline $\mathrm{V}_{2} \mathrm{O}_{5}$ for samples containing high $\mathrm{V}_{2} \mathrm{O}_{5}$ content above $10 \mathrm{wt} \%$ are in good agreement with the results of the IR spectra in Figure l. Namely. this is because $\mathrm{V}_{2} \mathrm{O}_{5}$ loading exceeding the formation of monolayer on the surface of zirconia is well cnstallized ${ }^{\text {it... }}$ Moreover the increase in $\mathrm{V}_{3} \mathrm{O}_{i}$ content resulted in the appearance of an additional sigmal with a peak at $-800 \mathrm{ppm}$. The intensity of the signal increased with an increase in $\mathrm{V}_{2} \mathrm{O}_{5}$ loading. Different peak positions normally indicate the differences of the spectral parameters and are observed due to different local environments of vanadium muclei. ${ }^{4-i 3}$ Thus species at $-500 \sim-650$ ppm and $-800 \mathrm{ppm}$ can be attributed to two types of tetrahedral vanadium complexes with different oxygen environments. Namely: the signals at $\mathbf{- 5 0 0}-6 \mathbf{5 0}$ ppm can be attributed to the surface vanadium complexes containing $\mathrm{OH}$ groups or water molecules in their coordination sphere. ${ }^{i j}$ 


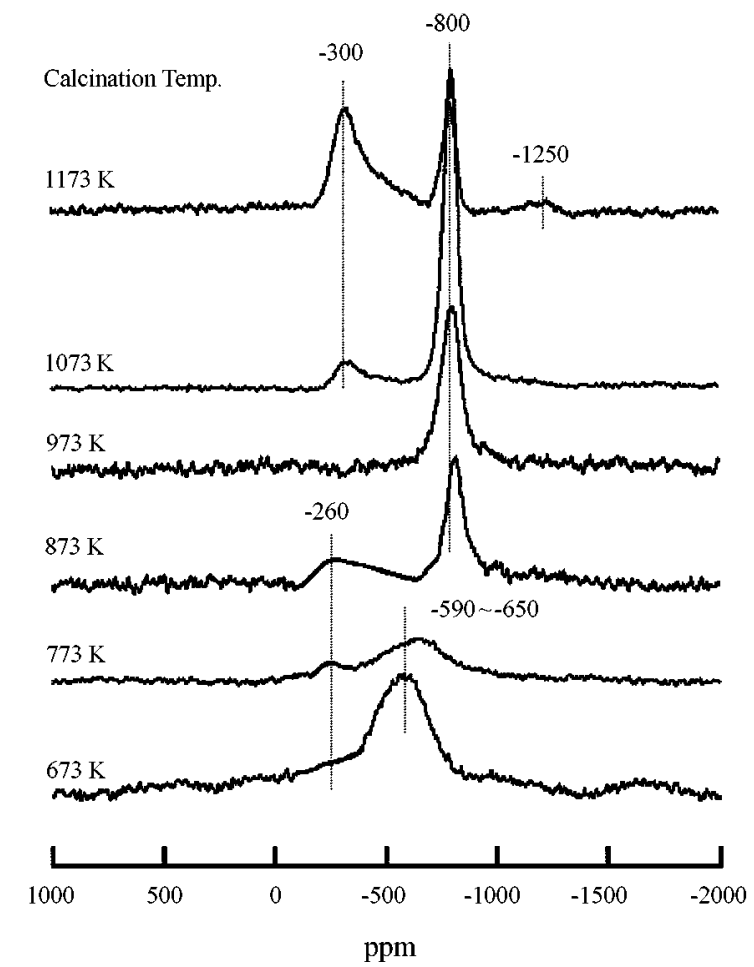

Figure 6. Soid-state ${ }^{5} \mathrm{~V}$ NMR spectra of $3 \mathrm{~V}_{2} \mathrm{O}_{-1}-15 \mathrm{MoO}, / 7 \mathrm{IO}_{2}$ cataly sts calcined at different temperatures.

because the evacuation treatment decreases the intensities remarkably. On the other hand, the signal at $-800 \mathrm{ppm}$ is due to the surface tetrahedral vanadium complexe which does not contain $\mathrm{OH}$ groups or adsorbed water molecules.

It is necessary to examine the effect of calcination temperature on the surface of the vanadium oxide structure. The spectra of $3 \mathrm{~V}_{2} \mathrm{O}_{5}-15 \mathrm{MoO}_{3} / \mathrm{ZrO}_{2}$ containing a lower vanadium oxide content and calcined at various temperatures are shown in Figure 6. The shape of the spectnum is very different depending on the calcination temperature. For both samples calcined at lower temperatures $(673-773 \mathrm{~K})$, two peaks at about $-260 \mathrm{ppm}$ and $-500 \sim-650 \mathrm{ppm}$ due to the octahedral and tetrahedral vanadium-oxygen structures are shown. indicating the monolayer dispersion of $\mathrm{V}_{2} \mathrm{O}_{5}$ on the $\mathrm{ZrO}_{2}$ surface. These results are in good agreement with the results of the IR spectra in Figure 2. However. for simples calcined at $873 \mathrm{~K}$. in addition to the above two peaks. a peak at $-800 \mathrm{ppm}$ due to crystalline $\mathrm{ZrV}_{2} \mathrm{O}_{2}$ appeared. indicating the formation of a new compound from $\mathrm{V}_{2} \mathrm{O}_{2}$ and $\mathrm{ZrO}_{2}$ at a high calcination temperature. For samples calcined at 873$1073 \mathrm{~K} . \mathrm{X}$-ray diffraction patterns of $\mathrm{ZrV}_{2} \mathrm{O}$; were observed. Roozeboom et al. reported the formation of $\mathrm{ZrV}_{3} \mathrm{O}$ from $\mathrm{V}_{2} \mathrm{O}_{5}$ and $\mathrm{ZrO}_{2}$ at a calcination temperature of $873 \mathrm{~K}^{-16}$ At a calcination temperature of $973 \mathrm{~K}$ only a peak at $-800 \mathrm{ppm}$ due to the $\mathrm{ZrV} \leq \mathrm{O}$ - phase appeared. saving that most of the $\mathrm{V}_{2} \mathrm{O}_{5}$ on the surface of zirconia was consumed to form the $\mathrm{ZrV}_{2} \mathrm{O}$ - compound. Howerer at a calcination temperature of $1073-1173 \mathrm{~K}$ we can obsere only a sharp peak of crystalline $\mathrm{V}_{2} \mathrm{O}=$ at -300 and about $-1250 \mathrm{ppm}$. indicating the decomposition of $\mathrm{ZrV}_{2} \mathrm{O}$. These results are in good agree-

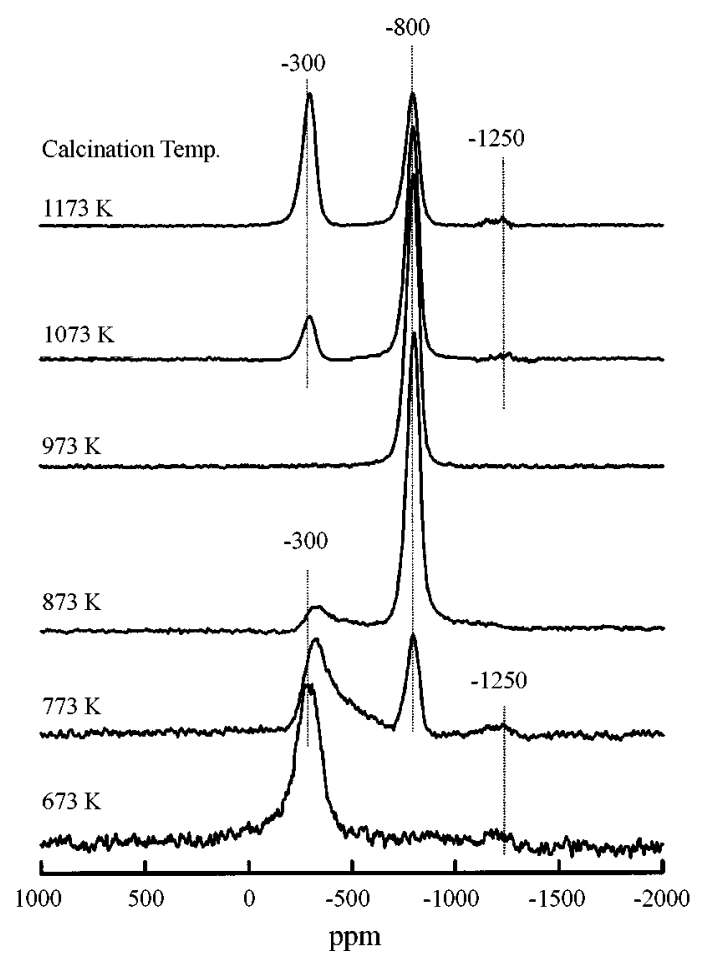

Figure 7. Solid-slate ${ }^{51} \mathrm{~V}$ NMR spectra of $20 \mathrm{~V}_{2} \mathrm{O}_{3}-15 \mathrm{MoO}, 3 / \mathrm{ZOO}_{2}$ catalysts calcined at different temperatures

ment with those of IR spectra in Figure 2.

The spectra of $20 \mathrm{~V}_{2} \mathrm{O}_{5}-15 \mathrm{MoO}_{3} / \mathrm{ZrO}_{2}$ containing a higher vanadium oxide content than monolayer loading and calcined at various temperatures are shown in Figure 7. Unlike $3 \mathrm{~V}_{2} \mathrm{O}_{5}-15 \mathrm{MoO}_{3} / \mathrm{ZrO}$, for $20 \mathrm{~V}_{2} \mathrm{O}_{5}-15 \mathrm{MoO}_{3} / \mathrm{ZrO}$ = calcined even at lower temperatures $(773 \mathrm{~K}$ ) a sharp peak due to crystalline $\mathrm{V}_{2} \mathrm{O}_{5}$ appeared at $-300 \mathrm{ppm}$ together with a peak at $-800 \mathrm{ppm}$ due to the tetrahedral surface species. However. for samples calcined at $873 \mathrm{~K}$. in addition to a peak at -300 ppm due to cry stalline $V_{2} \mathrm{O}_{5}$ a sharp peak at $-800 \mathrm{ppm}$ due to $\mathrm{ZrV}_{2} \mathrm{O}$ - compound appeared. As shown in Figure 7, the peak intensity of $\mathrm{ZrV}_{2} \mathrm{O}$ - increased with an increase in calcination temperature, consuming the content of crystalline $\mathrm{V}_{2} \mathrm{O}_{5}$. Consequently, at a calcination temperature of $973 \mathrm{~K}$ only a peak due to the $\mathrm{ZrV}_{2} \mathrm{O}_{\text {}}$ phase appeared at $-800 \mathrm{ppm}$. At a calcination temperature of $1073 \mathrm{~K}$. a sharp peak of cristalline $\mathrm{V}_{2} \mathrm{O}_{5}$ at -300 ppm due to the decomposition of $\mathrm{ZrV}_{2} \mathrm{O}$ was again observed. However. unlike $3 \mathrm{~V}_{2} \mathrm{O}_{5}-15 \mathrm{MoO}_{3} / \mathrm{ZrO}$. for $20 \mathrm{~V}_{2} \mathrm{O}_{-}-15 \mathrm{MoO}_{3} / \mathrm{ZrO}_{2}$, the $\mathrm{ZrV}_{2} \mathrm{O}_{2}$ compound was not decomposed completely at $1073 \mathrm{~K}$. leaving some $\mathrm{ZrV}_{2} \mathrm{O}-$. It seems likely that it is very difficult for all $\mathrm{ZrV}_{2} \mathrm{O}$ - to decompose for $1.5 \mathrm{~h}$ because a large amount of $\mathrm{ZrV}, \mathrm{O}$ - was formed in the case of $20 \mathrm{~V}_{2} \mathrm{O}_{5}-15 \mathrm{MoO}_{4} / \mathrm{ZrO}_{2}$

Surface Properties. The specific surface areas of some samples calcined at 673 and $773 \mathrm{~K}$ for $1.5 \mathrm{~h}$ are listed in Table 1 . The presence of vanadium oxide and molybdenum oxide influences the surface area in comparison with the pure $\mathrm{ZrO}_{2}$. Specific surface areas of $\mathrm{V}_{2} \mathrm{O}_{5}-\mathrm{MoO}_{3} / \mathrm{ZrO}_{2}$ samples are larger than that of pure $\mathrm{ZrO}_{2}$ calcined at the same temperature. It seems likely that the interaction between 
Table 1. Specific surlace areas of some $\mathrm{V}_{2} \mathrm{O}_{5}-15 \mathrm{MoO}_{3} / \angle \mathrm{rO}_{2}$ semples calcined at $673 \mathrm{~K}$ and $773 \mathrm{~K}$

\begin{tabular}{|c|c|c|}
\hline Catalysts & $\begin{array}{c}\text { Surtace area } \\
\left(\mathrm{m}^{2} \mathrm{~g}-673 \mathrm{~K}\right)\end{array}$ & $\begin{array}{l}\text { Surface area } \\
\left(111^{2} \mathrm{~g} .773 \mathrm{~K}\right)\end{array}$ \\
\hline $\mathrm{ZrO}_{2}$ & 185 & 122 \\
\hline $1 \mathrm{~V}_{2} \mathrm{O}_{5}-15 \mathrm{MoO}_{3} \mathrm{ZrO}_{2}$ & 219.9 & 218.6 \\
\hline $3 \mathrm{~V}_{2} \mathrm{O}_{5}-15 \mathrm{MoO}_{3}: \mathrm{ZrO}_{2}$ & 236.2 & 221.4 \\
\hline $5 \mathrm{~V}_{2}\left(\mathrm{O}_{5}-15 \mathrm{MoO}\right)_{3} / \mathrm{s} \mathrm{O}_{2}$ & 223.8 & 216.8 \\
\hline $10 \mathrm{~V}_{3}\left(\mathrm{O}_{5}-15 \mathrm{MoO}\right)_{3} / \mathrm{s}\left(\mathrm{O}_{2}\right.$ & 207.9 & 165.6 \\
\hline $15 \mathrm{~V}_{3}\left(\mathrm{O}_{5}-15 \mathrm{MoO}\right)_{3} / \mathrm{sO}$ & 170.1 & 148.6 \\
\hline $20 \mathrm{~V}_{2}\left(\mathrm{O}_{5}-15 \mathrm{MoO}\right)_{3} / \mathrm{sO} \mathrm{O}_{2}$ & 164.5 & 147.1 \\
\hline
\end{tabular}

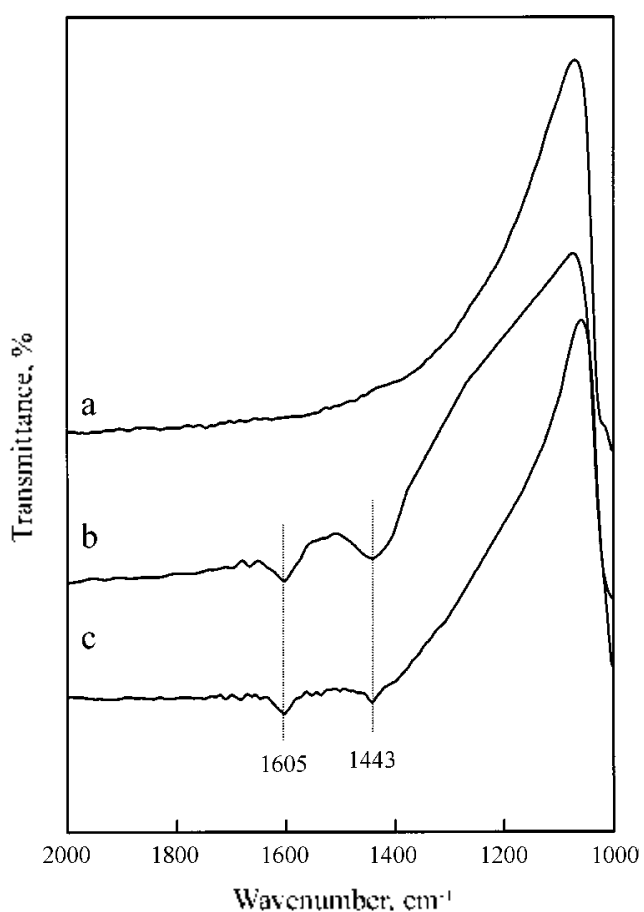

Figure 8. Inftared spectra of $\mathrm{NH}_{3}$ adsorbed on $15 \mathrm{~V}_{3} \mathrm{O}_{5}-15 \mathrm{MoO}_{3} /$ $\angle \mathrm{rO}=\left(773\right.$ ). (a) background of $15 \mathrm{~V}_{2} \mathrm{O}_{5}-15 \mathrm{MoO}_{3} / \angle \mathrm{rO} \mathrm{O}_{2}$ cwacualed at $673 \mathrm{~K}$ for 1 h. (b) NII, 20 torr) adsorbed on sample a. (c) sample b evacuated at $50.3 \mathrm{~K}$ for $0.5 \mathrm{~h}$.

vanadium oxide (or molybdenum oxide) and $\mathrm{ZrO}_{2}$ protects cataly sts from sintering. ${ }^{\text {. }}$

lnfrared spectroscopic studies of ammonia adsorbed on solid surfaces have made it possible to distinguish between Brönsted and Lewis acid sites. ${ }^{23.5 .1 .}$ Figure 8 shows the IR spectra of ammonia adsorbed on $15 \mathrm{~V}_{2} \mathrm{O}=-15 \mathrm{MoO}_{3} / \mathrm{ZrO}=$ calcined at $773 \mathrm{~K}$ and evacuated at $673 \mathrm{~K}$ for $1 \mathrm{~h}$. For $15 \mathrm{~V}_{2} \mathrm{O}_{5}-15 \mathrm{MoO}_{3} / \mathrm{ZrO}_{2}$ the bands at $14+3$ are the characteristic peaks of ammonium ion. which are formed on the Brönsted acid sites and the absorption peaks at $1605 \mathrm{~cm}^{-1}$ are contributed by anmonia coordinately bonded to Lewis acid sites ${ }^{m-n-1}$ indicating the presence of both Brönsted and Lewis acid sites. Other samples having different vanadium content also showed the presence of both Lewis and Brönsted acids. Therefore. these $\mathrm{V}_{2} \mathrm{O}_{i}-\mathrm{MoO}_{3} / \mathrm{ZrO}_{2}$ samples can be used as cataly sts for Lewis or Brönsted acid catalysis.

\section{Conclusions}

On the basis of the results of FTIR. Raman spectroscopy. solid-state ${ }^{51} \mathrm{~V} N M R$ and $X R D$, at a low calcination temperature of $773 \mathrm{~K}$. it has been found that vanadium oxide up to $10 \mathrm{wt} \%$ was well dispersed on the surface of zirconia. However, when the $\mathrm{V}_{2} \mathrm{O}_{5}$ loading exceeded $15 \mathrm{wt} \%$ (the amount equal to cover by monolayer on the surface of zirconia). the $\mathrm{V}_{2} \mathrm{O}_{3}$ existed in well crystallized state. The $\mathrm{ZrV}_{2} \mathrm{O}$ - compound was formed by the reaction of $\mathrm{V}_{2} \mathrm{O}_{5}$ and $\mathrm{ZrO}_{2}$ at $873 \mathrm{~K}$ and it decomposed into $\mathrm{V}_{2} \mathrm{O}_{5}$ and $\mathrm{ZrO}_{2}$ at $1073 \mathrm{~K}$ : these results were observed in FTIR spectra and solid-state ${ }^{51} \mathrm{~V}$ NMR. Infrared spectroscopic studies of anmonia adsorbed on $\mathrm{V}_{2} \mathrm{O}_{5}-\mathrm{MoO}_{3} / \mathrm{ZrO}_{2}$ catalysts showed the presence of both Lewis and Brönsted acids.

Acknowledgment. This work was supported by Korea Research Foundation Grant (KRF-2001-041-E00312).

\section{References}

1. Argile. M. D.: Chen, K.: Bell. A. T.: Iglesia, F. J. C'atal. 2002. 208. 139 .

2. Miyala. H.: Kohno. M.: Ono. T.: Ohno. T.: Hatayama. F. J. Chem. Soc. Faradon Trams. / 1989.85.3663.

3. Lakshmi. L. J.: Ju. L.: Alyea. E. Lomgmmir 1999. 15. 3521.

4. Bulusher, D. A.: Kiwi-Minster. I... 7.aikotskii. V. I.: Renken, A. J. Catal 2000. 193. 145.

5. Feng. T.: Vohs. J. M. J. Catal. 2002, 208, 301

6. Busca. G.: Elmi. A. S.: Forzatti. P. J. Ihws. Chem. 1987. 91. 5263.

7. Narayama. K. V.: Masthan. S. K.: Rao. V. V.: Raju. B. D.: Rao. P. K. Catal. Common. 2002. 3. 173.

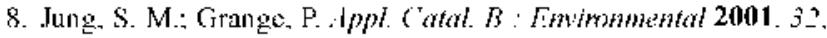
1230 .

9. Alemany. I.. J. J Jicti, I... Ferlazzo, N.: Forzatti. P.: Busca. G.: Giamello. E.: Bregani. F. J. Caht. 1995. 155. 117

10. Centeno. M. A.: Malet. P': Carrizosa. 1.: Odriozola. J. A. J. Ithys. Chem. B 2000. Hot. 3310

11. Matralis. H. M.: Ciardelli, M.: Runet, M.: Grange. P. f. Catal. $1995,157.368$

12. F.lmi, A. S.: Tronoconi. F.: Cristiani, C.: Martin, J. P. G.: Forzatti, P. Ind Eng. Chem. Res. 1989.84.387.

13. Lapina. O. B.: Shubin. A. A.: Nosov. A. V.: Bosch. E.: Spengler. J.: Knözinger. H. J. Ithss. Chem. B 1999.103.7599.

14. Gao, X.: Jelung. I.-M.; Wachs. I. F. .J. C'atal 2002. 209, t.3.

15. Iatasama, $\Gamma$.: Olmo. T.: Maruoke, T: Ono, T.: Mivata. II. $J$. Chem Soc. Faraday Trans 1991, 87, 2629.

16. Reddy: B. M.: Ganesh. I.: Reddy. E. P:: Fernande $\angle$. A.: Smimiotis. P. G. J. Phws. Chm B 2001. 105. 6227.

17. Centi. G.: P'inelli. D.: Trifrro. F.: Ghoussoub. D.: Guelton. M.: Gengenbre, J...J. Catal 1991, /30.238.

18. I.i, M.: Shen, I. . Cotal. 2002. 205. 248.

19. Scharf. U.: Schraml-Marth. M.: Wokaun, A.: Paiker. A. J. Che'm. Soc. Firadan Troms. 1 1991.87.3299.

20. Monaci. R.: Rombi. E.: Solinas. V: Sorrentino. A.: Santacesania. E.: Colon. G. .tppl. Calal .t: Genera/ 2001. 211. 203.

21. Solm, I. R.; Park, M. Y.: Pae, Y. I. Bull Korean Che'm. Soc. 1996. I7.274

22. Solm, I. R.; Kim, I. G.; Kowm, T. D.; Park, Г.. H. Langmuir 2002, IS. 1666

23. Ward. D. A.: Ko. E. I. J. Catal. 1994. 150. 18.

24. Hassan. El-B.: Mun. S. P.J. Ind Eng. Chem 2002. 8. 359.

25. Ifsu, C. Y: I Jeimbuch, C. R.: Ames, C. T: Gates, B. C. J. ( $/ \mathrm{k}^{2} \mathrm{~m}$. Soc. Chem. Commm 1992, 1645 . 
26. Wan. K. T:: Khoun. C. B.: Davis. M. E. J. Catal. 1996. I58.311. 27. lglesia. E.: Soled. S. L.: Kramer. G. M. J. Catal 1993. 14t. 238.

28. Ebitani. K.: Konishi. J.: Hattoni. H. J. Catal. 1991, 130. 257.

29. Vaudagna, S. R.: Comclli, R. A.: Canavese. S. A.; Figoli. N. S. J. ('atal. 1997, 169, 389 .

30. 7hao, B.: Wang. X.: Ma. II.: Tang. Y. J. Mol Catal A:Chemical 1996. 108. 167

31. Larsen. Gr: Lotero. E.: l'arra. R. D. in Proc: Hhh Int. Congl: Catal. 1996. 543.

32. Kera. Y.: I Jirota. K. J. Phns (Chem. 1969, 73, 39.37

33. Colc, D. J.: Cullis, C. F.: IJucknal], D. J. J. (Hem. Soc. Faraday Trans. $11976,72,2185$.

34. Solm. J. R.: Cho. S. G.: P'ue. Y. I.: Hayashi. S. J. Cafal. 1996. I59. 170 .

35. l'ark. E. H.: Lee. M. H.: Sohn. I. R. Bull Sonam Chom. Soc: $2000,21,913$.

36. Soln, J. R:- Doh. I. J.: Pac, Y. I. Langmir 2002, IS, 6280

37. Mori. K.: Mivamoto. A. Murakami. Y. J. (Wem. Soc. Fowado Trans: / 1987.83.3303.

38. Bjorklund. R. B.: Odenbrand. C. U. 1.: Brandin. J. G. M.: Anderson. L. A. H.: Liedberg. B. J. Catal. 1989. 119. 187.

39. IJighticld, J. G.: Moftat, J. B., J. Catal. 1984, $89,177$.

40. Roozcboom, F.: Mittelmelijer-I Iazeleger, M. C.: Moulijı. J. A. Medema, J.: de Becr, U. II. J.: Gelling. P. J. J. Ph.s (hem. 1980. 84.2783.

41. Desikan. A. N.: Huang. L.: Ovama. S. I. J. Thns. Chem. 1991. 95.
10050

42. Liu. L.: Chen. Y.J. Catal. 1948. 177. 314

43. Dines. I. J.: Rochester. C. H.: Ward. A. M. J. Cham. Soc. Faraden Trans. / 1991. 87,653.

44. Dufresne, P.: Payen, E.: Grimblot, J.: Bonnclle, J. P. J. Phs. (Wem 1981. 85. 2344.

45. Hu. H.: Wachs. 1. E. J. Hhw Ch'm. 1945. 99. 10897.

46. Ramis. G.: Cristiani. C.: Forzolti. 1': Busca. G. J. Catal, 1990. I24. 574 .

47. Schild, C. H.: Wokautr. A.: Köpol, R. A.: Baiker, A. J. Catal. $1991,130.657$

48. Scheithauer, M.: Grasselli, R. K.: Knözinger. II. Iangmuir 1998 , If. 3019 .

49. Eokert. H.: Waclss. I. E. J. Ihons. Chm 1989. 93.6796.

50. Reddy. B. M.: Reddy. E. I:: Srimivas. S. T:: Mastitihim. V. M.: Nosov: N. V. I apina, O. B. J. Phus (hem. 1992. 96. 7076.

51. I. Costumer. I.. R.: Taouk, B.: I. Meur, M.: Payen. F..: Guelton, M.: Grimblot. I. J. Phys (Wem 1998. 92, 1230.

52. Larsen. G.: Lotero. E.: P'etkovic. L. M.: Shobe. D. S. J. Catal. 1997. 169.67.

53. Alanasiev. P': Geantel. C.: Breysse. M.: Coudurier. G.: Vedrine. I. C. J. (hem. Soc. Faraday Trans. / 1994. 190. 193.

54. I.artubia, M. A.: Ramis, G.: Busca. G. Lppl ('alal. B: Fowiromental 2000, 27. I.145.

55. Salsuma. A.: Hatlori. A.: Mizulani. K.: Furula. A.: Miyamolo. A.: Hallori. T.: Murakami. Y. J. Phs. Chem. 1988. 92.6052. 